\title{
Philosophical Explication of Requirements on the Process of Education - Novelty or Relic?
}

\author{
[Filozofická explikácia požiadaviek na proces edukácie - \\ nóvum alebo prežitok?]
}

\author{
Maria Pisonova
}

\section{DOI: $10.18355 /$ XL.2016.09.01.83-90}

\begin{abstract}
Abstrakt
Príspevok pojednáva o niektorých filozofických východiskách procesu edukácie, ktoré majú zásadný vplyv na jeho kreovanie dodnes. Často ide o vzájomne si odporujúce tvrdenia a názory, ktoré ale $\mathrm{v}$ konečnom dôsledku sledovali jeden spoločný ciel': vytvorit' pevné základy vzdelanosti vedúce k dosiahnutiu kvalitných edukačných výstupov. Ich význam a využitie v pedagogickej praxi tvorí významnú súčast' pregraduálnej prípravy učitel'ov nielen ako súčast' dejín pedagogiky, ale aj didaktiky, pedeutológie, andragogiky, ako aj ostatných pedagogických disciplín, študijných odborov a študijných programov.

Klúčové slová

filozofia, edukácia, výchova, vzdelávanie, vzdelanie, filozofické východiská, nomotetické vedy, idiografické vedy

\section{Úvod}

V praxi sa stretávame s niektorými filozofickými explikáciami procesu edukácie, ktoré vychádzajú z rovnakých, ale aj rozdielnych tvrdení. Ich spoločným menovatel’om je permanentná determinácia procesu edukácie až do súčasnej podoby. V zásade ide o rozdielny filozofický pohl'ad na chápanie sveta a následne výchovy, ktorý je pretransformovaný do konkrétnych vedných disciplín. Výsledkom tohto vplyvu sú rôzne názory na proces edukácie, ktoré niekedy zachádzajú až do antagonistickej intolerancie. Často je to ale o nepochopení, resp. povrchnom chápaní významu jednotlivých tvrdení, výsledkom čoho môže byt' popieranie prínosu nomoteticky orientovaných vied do procesu edukácie. Tieto prístupy sa totiž objavujú v pregraduálnej príprave učitel'ov iba sporadicky napriek tomu, že ich význam je nepopieratel'ný.
\end{abstract}

\section{Súčasné chápanie pojmu edukácia}

Termín edukácia je relatívne nový pojem. Vo filozofii výchovy sa ním označuje proces výchovy vzt’ahujúci sa iba na človeka. Je odvodený z lat. educatio (vychovávanie). Vo všeobecnej pedagogike a didaktike sa používa ako synonymum $\mathrm{k}$ termínu vzdelávanie, resp. výchovno-vzdelávací proces, zároveň ako ekvivalent anglického slova education, čo v slovenskom jazyku predstavuje pojem edukácia. Průcha a kol. (1998: 60).

V tejto súvislosti je potrebná podrobnejšia interpretácia uvedeného slova. Pokúsil sa o ňu (Švec, 2002: 318), podl'a ktorého je súčast’ou edukácie:

- Vzdelávanie (a vychovávanie a vycvičovanie) ako sústava inštitucionálne organizovaných aktivít (v školstve, osvete a inde) zacielených na celoživotné rozvíjanie znalostí, schopností, hodnotových postojov a iných osobných kvalít potrebných pre spôsobilost' v budúcich rolách (školáka, občana, pracovníka, 
manžela, rodiča a v iných životných aktivitách), jednotlivca ako stávajúcej sa sebarealizačnej osobnosti v spoločnosti. ${ }^{1}$

- Slovné spojenie „výchova (v užšom slova zmysle) a vzdelávanie“ a to zvyčajne vo

význame pojmu citovej, vôl’ovej a snahovej výchovy (socioafektívnej edukácie) a intelektovej či rozumovej výchovy (kognitívnej edukácie).

- Výučba (učitel'stvo) a mimovýučbová výchova, resp. sociálno-výchovná starostlivost' (vychovávatel'stvo, poradenstvo a iné).

- Výchova v širšom slova zmysle.

Švec (2002) a Petlak $(2008,2012)$ zhodne konštatujú, že vzdelanie a vychovanie je výsledkom procesu edukácie.

V nadväznosti na uvedené tvrdenia Průcha (1997: 60) charakterizuje edukačné procesy ako činnosti, pri ktorých sa nejaký subjekt učí obvykle za pôsobenia (priameho alebo sprostredkovaného) iného subjektu, ktorý vyučuje alebo inštruuje. V ňom dochádza ku vzájomnému ovplyvňovaniu medzi edukantom a edukátorom, pri čom edukantom je každý subjekt učenia a edukátorom každý aktér vyučovania alebo inej intencionálnej edukačnej aktivity.

\section{Filozofické východiská a súčasné pohl'ady na proces edukácie}

Odborná verejnost' si v ostatnom období kladie stále častejšie otázku, ako realizovat' proces edukácie, aby sa dosiahol čo najlepší efekt v podobe jej výstupov. Možno by ale stačilo dôslednejšie implementovat' do praxe filozofické východiská, resp. odkazy mnohých významných osobností, ktoré siahajú už do obdobia 400 rokov pred n. 1.. V tom čase začali ovplyvňovat' vzdelanie dva smery: retoricko pragmatický a filozoficko - vedecký. Do rozvoja vzdelanosti významne zasiahol okolo 300 rokov pred n. 1. Helenizmus, kedy začal vznikat' najmä v Aténach, Pergamone, či Rodose istý druh vedeckej „vel'koprevádzky“ s rozsiahlymi knižnicami, archívmi a učitel'skými inštitútmi (Reble, 1995: 29). V tejto súvislosti nemožno opomenút' významného rímskeho teoretika pedagogiky M. F. Quintiliana. Svoje filozofické odkazy zhrnul do jeho hlavného diela Institutio oratoria (Výchova rečníka). Práve ono sa neskôr stalo najmä pre humanistov vel'kou autoritou. Quintilianus totiž podobne ako Cicero poukazuje na l'udsko - morálne aspekty utvárania charakteru človeka.

Aj ked' nie je možné spomenút' všetkých významných filozofov, ktorí formovali osobnost' človeka, nemožno zabudnút' na posolstvo J. A. Komenského, ktorý tvrdil, že podstata vzdelania spočíva podobne ako v prírode $\mathrm{v}$ dodržiavaní princípu usporiadanosti (Reble, 1995: 91).

V dvadsiatom storočí sa (Dilthey, 1980: 335) vyjadril nasledovne: „, Naše JA je spojené s inými osobami a vonkajšimi predmety, realita tohto osobného JA cudzich osôb a veci okolo nás, rovnako ako pravidelné vzt'ahy medzi nimi - to tvori kostru našej životnej skúsenosti. " Uvedený citát vytvára priestor na diskusii o dejinnosti človeka, ktorú (Dilthey, 1958: 278) charakterizuje ako sebaporozumenie a sebavymedzenie v časovom a dejinnom kontexte, t.j. potrebu osobnej identifikácie. Jeho názory boli ovplyvnené výskumami humanitných vied, ale najmä historickými, v ktorých sa zameriaval na filozofický základ humanitných vied, pri čom odmietal idealistické špekulácie a mechanicko - pozitivistické postoje (Reble, 1995: 273).

${ }^{1} \mathrm{~V}$ odbornej anglickej literatúre sa uvádza rozdiel medzi edukáciou na jednej strane a odborným výcvikom a odborným vzdelávaním na druhej strane, napr. z hl'adiska poslaní, účelov, obsahu, ciel’ových programov, dížky trvania, univerzality versus selektivity, hlavného zdroja financovania a z hl'adiska iných charakteristík. 
Ked’že sa v tomto príspevku budeme venovat' aj nomotetickým aspektom edukácie, je potrebné uviest', že Diltheyho myslenie bolo v rozpore s Windelbandovým.

$\mathrm{V}$ súvislosti s pojmom vzdelanie uvádzame Schelerovo chápanie tohto slova $\mathrm{v}$ zmysle tvorby a sebatvorby, ktoré zasa vzniklo pod vplyvom klasického humanitného ideálu, vyjadreného v nemeckom jazykovom a myšlienkovom prostredí pojmom Bildung. Tento pojem podl'a Schelera (Scheler, 1976: 85) vyjadroval predstavu harmonického a všestranného rozvoja l'udského potenciálu, schopností a dispozícií.

O dvadsat' rokov neskôr uviedol (Patocka, 1996: 404), že ciel'om výchovy je privádzat' tých, na ktorých pôsobíme do „pravej l’udskej podoby“. Tú chápal ako l'udskú authenticus (sám, vlastný, svoj).

Jeho presvedčenie, aj ked' v inom chápaní, doplnil neskôr (Rogers, 1999, s. 19). Tento významný psychológ charakterizuje autentickost', resp. kongruenciu, ako schopnost' poznat' a uvedomovat' si svoje silné a slabé stránky, svoj potenciál, ale najmä schopnost' znášat' dôsledky svojich rozhodnutí. Ked' je učitel' v edukačnom procese sám sebou, je pre žiakov transparentný, resp. čitatel’ný. Znamená to, že nepoužíva žiadnu profesionálnu alebo osobnú fasádu (masku). Tým sa vytvára väčší priestor na facilitáciu osobnostnej zmeny žiaka v zmysle vyššie uvedenej l'udskej autenticity. Termín kongruencia vznikol pôvodne na označenie vel'kej skupiny javov, ktoré sú dôležité nielen pre terapiu, ale aj pre celú medzil'udskú interaktivitu. Kongruencia predstavuje presný súlad medzi prežívaním a uvedomovaním a komunikáciou. (Sollarova, 2005, s. 115).

Svoj pohl'ad na filozofický obraz sveta ponúka aj (Pelcová, 2010: 136). Podl’a nej k povahe l'udského sveta, sveta dejín a kultúry patrí pevný systém vztahov, ktoré nemajú kauzálny charakter. Východiskom filozofie výchovy je podla Daneka (Danek, 2011: 7 - 8) filozofický obraz sveta spojený s reálnymi úvahami o pôvode a význame človeka v ňom. Zároveň tvrdí, že špecifikom filozofického obrazu je rastúce vedomie o celkovom poslaní a úlohe života, sveta a človeka v ňom.

V zmysle vyššie uvedených požiadaviek sa stále častejšie skloňuje požiadavka profesijného rozvoja edukátora, ktorým je aj učitel'. Pavlov (2013: 23) chápe profesijný rozvoj učitel'a ako nástroj profesionalizácie učitel'stva, permanentného vyrovnávania sa so zmenami, čo má v dlhodobom výhl'ade vplyv na kvalitu výchovy a vzdelávania. Praktické uplatnenie uvedených odporúčaní však závisí od pedagogických kompetencií vysokoškolských učitel'ov, ktorých význam a potreba od konca dvadsiateho storočia stále stúpa. (Miklosikova, 2015: 13).

Medzi oblasti, ktorým nie je v súčasnej učitel'skej príprave venovaná náležitá pozornost', zarad'uje Hašková prezentáciu, akumuláciu a reprodukciu informácií (Haskova, 2004: 89). S vyššie uvedenými tvrdeniami súhlasí aj Veteška, ktorý akcentujúce potrebu reflexie zmien vzdelávacích potrieb ako jedného z najvýznamnejších faktorov rozvoja jedinca a spoločnosti (Veteska, 2011:11).

Nomotetická veda podl'a Windelbanda sa zameriava na vytýčenie nezávislých postojov poznávajúceho subjektu tým, že vyjadruje terminologické výroky o samom objekte maximálnou objektivizáciou, zatial čo pre idiografické vedy je príznačná intersubjektivita. Windelband odmietal Diltheyho delenie na vonkajšiu a vnútornú skúsenost' a protiklad prírody a ducha (Natur-Geist) ako kritérium pre rozdelenie vied.

Základom nomotetických vied je podl'a Galileiho merat' všetko, čo je meratel'né a urobit' všetko, aby sa dosial' nemeratel'né stalo meratel'ným (Galilei in Poláková, 1996: 34). Rozdiel medzi nomotetickými (prospektívnymi) vedami a idiografickými (retrospektívnymi) vedami znázorňuje obrázok 1 . 


\section{METÓDY}

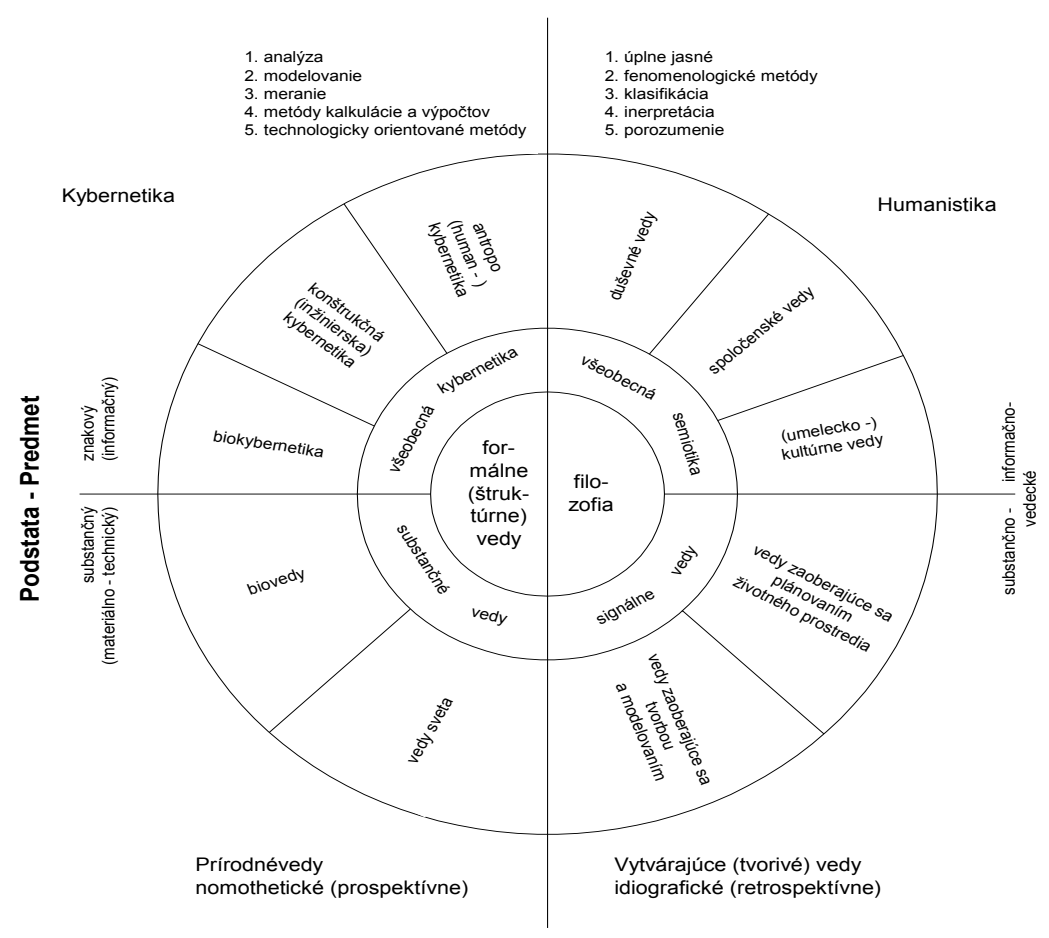

Zdroj: Windelband, W. 1921. Novověká filosofie. Preklad Procházka, R. Praha : Jan Otto, 1921.

Významným determinantom edukačného procesu je kybernetika, ktorá patrí medzi formálne štruktúrne vedy (vid'. obrázok 1). Jej zakladatel’om je americký matematik Norbert Wiener. ${ }^{1}$

Kybernetika pochádza (z gréckeho slova „kybernetes“ čo znamená kormidelník). Ako samostatný vedný odbor vznikla po 2 . svetovej vojne.

Podl'a Wienera je to veda zaoberajúca sa zákonitost'ami riadenia, oznamovania a kontroly informácií všetkých sústav a l'udskej spoločnosti.

Ide teda o disciplínu, ktorá skúma riadiace a regulačné procesy okrem iného aj v spoločenskom manažmente, kam riadenie edukačných procesov nepochybne patrí. Základné súčasti kybernetiky sú: teória systémov, teória informácie, teória regulácie, teória hier, teória algoritmov a teória samočinných počitačov. V inom vyjadrení predmetom skúmania kybernetiky je spracovanie informácií aj pre potreby riadenia edukačného procesu. Uvedenú nevyhnutnost' potvrdzuje aj Blížkovský (1992: 44), ktorý si myslí, že teoretickým základom komplexného prístupu k výchove je všeobecná teória systémov.

${ }^{1}$ Norbert Wiener, nazývaný aj ako „otec kybernetiky“ zhrnul kybernetické princípy v knihe vydanej v roku 1948 pod názvom: Cybernetics or control and communication in the animal and machine. 
Vychádzajúc $\mathrm{z}$ tejto premisy uviedol v jeho sústave vied o výchove požiadavku akcentácie teórie prostriedkov edukácie, resp. pedagogickej technológie, či pedagogickej technognózie, ktorú formuloval v roku 1992 vo svojej knihe Systémová pedagogika.

Pre kvalitnú edukáciu má vel'ký význam Kybernetická pedagogika. Je založená na kybernetických princípoch, ktoré aplikuje do procesu vzdelávania v intenciách tzv. Humánnej kybernetiky. Na jej makroúrovni ho výrazne determinujú aspekty sociálnej, hospodárskej, organizačnej a najmä politickej kybernetiky, pri čom na mezoúroveni sú to vzdelávacia kybernetika a jej subkomponenty ako informačná didaktika, systémová didaktika, vzdelávacia informatika a už spomínaná kybernetická pedagogika (Riedel, 1993: 53).

Odpoved' na otázku, v čom spočíva pochopenie nového učiva napr. žiakmi v základnej škole, je možné nájst' v požiadavke implementácie analytickej metódy, tzv. metódy Karteziánskeho rozkladu, ktorú zadefinoval Descartes. (Descartes, in 1970, 1992) ako súčast' metód skúmania nomotetických vied. Tie sa zameriavajú predovšetkým na,„...identifikáciu príčinných súvislostí vzdelávania umožňujúcich pristup k aproximácii psychoštruktúry a to postupnostou modelov s pribúdajúcou komplexitou posudzovania procesu výučby. “ V inom vyjadrení ide o skúmanie vzdelávacej situácie na princípe „postgalilejských“ prírodných vied, ktoré odmietajú zúžené pozitivistické skúmanie.

V procese projektovania výchovno-vzdelávacej situácie je preto potrebné postupovat' nasledovne:

1. Objekt skúmania (konkrétny obsah vzdelávania) je potrebné rozložit' na menšie komponenty a tie na d'alšie subkomponenty.

2. Subkomponenty je nevyhnutné skúmat' najskôr jednotlivo ako celok a neskôr analyzovat' vzt'ahy medzi nimi (ich intenzitu, orientáciu a pod.)

3. V závere tohto procesu by sa malo dospiet' $\mathrm{k}$ spätnej komplexnej syntéze vedúcej $\mathrm{k}$ dôkladnému poznaniu skúmaného pedagogického javu.

4. Len na základe realizácie vyššie uvedených krokov je možné vytvorit’ ideálny model obsahu vzdelávania.

Metóda karteziánskeho rozkladu sa realizuje prostredníctvom metód modelovania, kvantitatívnych relácií vyjadrených pomocou matematických znakových systémov a d'alších systémoch matematickej logiky.

Kybernetická pedagogika má svoje opodstatnenie aj v súčinnosti s ostatnými kybernetický orientovanými disciplínami. Jednou z nich je Systémová didaktika, ktorej autorom je H. Riedel. Jej ciel'om je podl'a autora optimalizovat' proces vyučovania na principe uplatňovania kybernetických teórií (Riedel, 1992: 113, Riedel, 1993: 52).

V súčasnosti je systémová didaktika v Nemecku základom pregraduálnej prípravy učitel'ov spoločne s ostatnými predmetmi učitel'ského základu. Dôležité je, že systémová didaktika ponúka učitel'ovi resp. projektantovi objektivizovanej výučby využitie nasledovných účinných nástrojov:

1. Všeobecne platný, diferencovaný a overitel'ný ciel'ový systém.

2. Účinné modely umožňujúce vysvetl'ovanie a odpoved'.

3. Diferencovaný plánovací systém, ktorý zabezpečuje realizáciu stanovených ciel'ov.

Podl'a Riedla je komplexný model systémovej didaktiky vybudovaný ako štvordimenzionálny model priestoru vzájomného pôsobenia učiaceho sa subjektu (napr. žiaka), operačného objektu (napr. vytváranie simulácií prostredníctvom softvérového programu) a vyučujúceho. Ide o nasledovné dimenzie: dimenzia operácií, učebného procesu, interakcii a objektov. Úspešná implementácia spomínaného modelu vyučovacej situácie umožňuje učitel'ovi okrem iného rozvíjat' kognitivne operácie žiaka, ktoré sú v systémovej didaktike predpokladom všetkých 
ostatných operácií. Umožňujú príjem informácií a ich uloženie do vedomia príjemcu. V tomto štádiu je dôležité, aby si učitel' uvedomil, kedy ide o tzv. rozpoznávanie. Informácie $\mathrm{z}$ okolitého prostredia sa dostávajú prostredníctvom receptorov do vedomia príjemcu, alebo sa do vedomia dostávajú informácie, ktoré pred tým mal žiak v pamäti. Ide o tzv. vybavenie. Od týchto faktorov bude závisiet' výber didaktických prostriedkov, ale aj načasovanie jednotlivých edukačných aktivít v rámci vyučovacej jednotky.

Pedagóg uplatňujúci vo vyučovaní princípy systémovej didaktiky by si mal tiež uvedomit', kedy rozvíja tzv. produkčné operácie, ktoré sa delia na transformujúce operácie (spájajúce informácie, ktoré si žiak už uvedomil a na základe toho vytvára $\mathrm{z}$ nich nové informácie) a formujúce operácie. Tie umožňujú žiakovi ich zapamätanie, vyhodnotenie, použitie originálneho, divergentného a konvergentného myslenia. Tieto operácie je vhodné uplatňovat' najmä v odbornom výcviku.

Konkretizáciou uvedeného sú dimenzie operačných objektov, ktoré majú pre učitel'a vel'ký význam. Od ich pochopenia a infiltrovania do vol'by didaktických prostriedkov totiž významnou mierou závisí dosiahnutie ciel'a výučby. Ide o nasledovné dimenzie operačných objektov: intenzita stimulu, konkrécia, informačné kanály, interné operácie, komplexita, znaková dimenzia a fakultatívne komponenty. Práve tieto spomínané dimenzie operačných objektov, resp. ich zohl'adňovanie v edukačním procese, by malo byt' súčast'ou každej vysokoškolskej prípravy učitel'ov.

\section{Záver}

Na základe prezentovaných filozofických východísk sa vynára otázka, do akej miery a či vôbec súčasná školská edukáciu využíva vyššie uvedené poznatky? Jednotlivé filozofické smery sa vyvíjali niekol'ko rokov, ba až generácií a sú podložené relevantnými výskumnými zisteniami.

V súčasnosti by možno stačilo dôslednejšie implementovat' do pregraduálnej prípravy učitel'ov, ako aj do d'alších foriem kontinuálneho vzdelávania aspoň využitie synergického efektu vyššie uvedených myšlienok a dôslednejšia aplikácia Rogersovej akceptácie (prijatia seba a iných bez určovania podmienok, resp. s rešpektom).

\section{Bibliograpic references}

BIROVA, J. 2013. About theoretical definitions of pluralistic and Pluricultural approaches. XLinguae, Vol. 6, no. 2 (2013), pp. 91-103. ISSN 1337-8384

BLIZKOVSKY, B. 1992. Ostrava: Amosium servis. ISBN 80-85498-18-9

DANEK, J. 2011. Uvod do filozofie vychovy. Praha: Univerzita Jana Amosa Komenskeho v Prahe. ISBN 978-80-7452-011-2

DESCARTES, R. 1970. Uvahy o prvni filosofii. Praha: Svoboda.

DESCARTES, R. 1992. Rozprava o metode. Praha: Svoboda.

DILTHEY, W. 1958. Gesammelte Schriften V. 1. Hälfte. Stuttgart: Teubner Verlagsgesellschaft.

DILTHEY, W. 1980. Zivot a dejinne vedomie. Bratislava: Pravda.

EGER, L. 2005. Technologie vzdelavani dospelych. Plzen: Zapadoceska univerzita v Plzni. ISBN 80-7043-398-1

GALILEI G. in POLAKOVA, E. a kol. 1996. Teoreticke zaklady technológie vzdelavania. Nitra: SAIS. ISBN 80-967425-1-5

HASKOVA, A. 2004. Technológia vzdelavania. Nitra: Pedagogicka fakulta UKF v Nitre. ISBN 80-8050-648-5

LAZAROVA, B. - PALACHOVA, VASTATKOVA J. - POL, M. - TROJAN, V. BOUDA, T. Working with data: Both and opportunity and challenge for schol leaders. In. The new educational Review, Vol. 40, pp. 81 - 94. ISSN 1732-6729 
KURINCOVA, V. 2011. School, Family and Community Partnerships. Your Hanbdbook for Action, 3rd edition. In The new educational Review. Vol. 26. Issue 4, pp. 285-288. ISSN 1732-6729

MALA, E. a kol. 2014. Key competencies of mentor teacher essential for successful mentoring of novice teachers. In XLinguae. Vol. 7. pp. 55-74. ISSN 1337 - 8384

MIKLOSIKOVA, M. 2015. Tvorivost a didakticka kompetence vysokoskolskych ucitelu technickych predmetu. Ostrava: Vysoka skola banska v Ostrave. ISBN 97880-8090512245

MISTRIK, E. 2008. Zbozstenie tela v narcizme a koniec postmodernej kultury. In Filozofia. Vol. 63 (4). Issue 4. pp. 344-351. ISSN 0046-385X

PALOUS, R. - SVOBODOVA, Z. 2011. Homo educandus - filosoficke teorie vychovy. Univerzita Karlova v Prahe: Karolinum. ISBN 978-80-246-1901-9

PATOCKA, J. 1996. Pece o dusi I. Praha: OIKOYMENH. ISBN80-86005-24-0

PAVLOV, I. 2013. Standardizacia profesijnych kompetencii ucitelov. Presov: Skola plus s. r. o. ISBN 978-80-970275-5-1

PELCOVA, N. 2010. Vzorce lidstvi. Praha: Portal. ISBN 978-80-7367-756-5

PETLAK, E. a kol. 2005. Diferenciacia ako prostriedok zefektivnenia pedagogickej cinnosti v skolskych zariadeniach. Nitra: Pedagogicka fakulta UKF v Nitre. ISBN 808050-900-X

PETLAK, E. 2012. Inovacie v edukacnom procese. Dubnica nad Vahom: Dubnicky technologicky institut. ISBN 978-80-89400-39-3

PETLAK, E. 1997. Vseobecna didaktika. Bratislava: IRIS. 270 s. ISBN 80-88778-492

PETROVA, G. - DUCHOVICOVA, J. 2014. Aktualne problemy zwiazane z przygotowaniem nauczycieli na Slowacji - anliza w kontekscie procesow transformacyjnych In Wychowanie na co dzien. Vol. 6, n. 249, pp. 7-11. ISSN 12307785

PISONOVA, M. a kol. 2014. Skolsky manazment pre studijne odbory ucitelstva a pripravu veducich pedagogickych zamestnancov. Bratislava: Univerzita Komenskeho. ISBN 978-80-223-3621-5

PISONOVA, M. 2012. Osobnostny rozvoj riaditela skoly - vychodiska a determinanty. Bratislava: Iura Edition. ISBN 978-80-8078-470-6

PISONOVA, M. - HASKOVA, A. - BITTEROVA, M. 2011. Didakticke prostriedky ako optimalizacny faktor procesu vzdelavania. Hradec Kralove: Gaudeamus. ISBN 978-80-7435-160-0

POKRIVČÁKOVÁ, S.: Komunikačné kompetencie vysokoškolského učitel'a. UKF, 2005. ISBN 808050814 3POLAKOVA, E. a kol. 1996. Teoreticke zaklady technológie vzdelavania. Nitra: SAIS. ISBN 80-967425-1-5

POL, M. 2007. Skola v promenach. Brno: Masarykova univerzita. ISBN 978-80210-4499-9

PORUBSKY, S. - KOSOVA, B. - VANCIKOVA, K. - BABIAKOVA, S. 2013. Premeny spolocnosti a perspektivy skoly. Banska Bystrica: Belianum. ISBN 978-8055705903

ROGERS, C. R. 1999. O osobnej moci. Bratislava: Persona. ISBN 80-967980-1-4

PRUCHA, J. a kol. 1998. Praha: Portal. ISBN 80-7178-252-1

PRUCHA, J. 1997. Moderni pedagogika. Praha: Portal. 495 s. ISBN 80-7178-170-3

REBLE, A. 1995. Dejiny pedagogiky. Bratislava: SPN,. ISBN 80-08-02011-3

RIEDEL, H. 1992. Neufassung des Modells zur Differenzierung von OperationsObjekten. Grundlagenstudien aus Kybernetik und Geisteswissenschaft 2, 33.

RIEDEL, H. 1993. Die Struktur der Unterrichts-Situation und die Objektivierbarkeit ihrer Funktionen. Grundlagenstudien aus Kybernetik und Geisteswissenschaft. RIEDL, H., 1997 In POLAKOVA, E. a kol. 1996. Teoreticke vychodiska technológie vzdelavania. Intra : Pedagogicka fakulta UKF a SAIS. ISBN 80-9674-25-1-5

89 
RUBACHA, M. - SIROTOVA, M. 2015. Child - rearing practices in Slovakia. In The new educatinal Review. Vo. 40 (2). pp. 17-25. ISSN 1732 - 6729

RYDL, K. 2003. Inovace skolskych systemu. Praha: ISV. ISBN 978-80-86642-17-8

SCHELER, M. 1976. Die Formen des Wissens ind die Bildung. In SCHELER, M. Gessamelte Werke. Bern: A. Francke Verlag.

SIROTOVA, M. 2015. Activating lecture within higher education - today and perspective. In: END 2015 : International Conference on Education and New Developments : Proceedings / edited by Mafalda Carmo. [S.1.] : WIARS, pp. 329-333. ISBN 978-989-99389-2-2

SOLLAROVA, E. 2005. Aplikacie pristupu zameraneho na cloveka (PCA) vo vztahoch. Bratislava: Ikar, 2005. ISBN 80-551-0961-3

SVEC, S.2002. Zakladne pojmy v pedagogike a andragogike. Bratislava: IRIS, 2002. $318 \mathrm{~s}$.

VERESOVA, M. - MALA, E. 2012. Stress, Proactive Coping and Self - Efficacy of Teachers. In Procedia Social and Behavioral Sciences, Vol. 55, pp. 294-300. ISSN 1877-0428

VETESKA, J. - Tureckiova, M. - Valicova, A. 2008. Blendet Learning as a Means to Differentiate and Optimise Corporate Training. In 7 th European Conference on E Learning. Vol. 2, pp. 599-606. ISBN 978-1-906638-22-1

VETESKA, J. 2011. Promeny skolniho vzdelavani v biodromalnim kontextu. Praha: Verlag Dashöfer. ISBN 978-80-86897-39-4

WINDELBAND, W. 1921. Novoveka filosofie. Preklad Prochazka, R. Praha: Jan Otto.

Words: 3017

Characters: 22593 (12, 55 standard pages)

Assoc. Prof. PaedDr. Mária Pisoňová, PhD.

Department of Education and Social Pedagogy

Institute of Educational Studies

Faculty of Education

Comenius University in Bratislava

Račianska 59

81334 Bratislava

Slovakia

pisonova@fedu.uniba.sk 